\title{
A Review of Students' Physical Fitness Students at MTSN, Lubuk Buaya, Padang
}

\author{
Dede Pratama Chandra ${ }^{1 *}$, Reno Eka Putra, and Ismail
}

\author{
${ }^{I}$ Faculty of Science and Sport, Universitas Negeri Padang Jl. Prof. Dr.Hamka, Air Tawar Barat, Padang, Indonesia \\ *Corresponding author. Email: pratamadede92@gmail.com
}

\begin{abstract}
Based on the observation conducted at MTsN Lubuk Buaya Padang, the students physical fitness is considered low. The purpose of this study was to determine the level of physical fitness of students. This research was a descriptive study. The population was 565 students of MTs Negeri Lubuk Buaya Padang. The sample was taken by purposive sampling technique, as many as 47 students. The data was collected by using Indonesia Physical Fitness test. The data were then statistically analyzed. The study states that the physical fitness of students was moderate $(70.21 \%)$. It can be concluded that the physical fitness of students should be improved involving all social environment such as parents, schools, and teachers who should pay more attention and maintain the Level of Physical Fitness ) students.
\end{abstract}

\section{Keywords: Physical Fitness, Physical Fitness Level}

\section{INTRODUCTION}

Whole Indonesian human development is an effort that is carried out consciously, planned and sustainable towards a change and progress and perfect improvement.Sports is one of the right ways to get and maintain body fitness. Sports activities also have a very important meaning in maintaining and developing self potential. "Sport is a systematic activity to encourage, foster and develop spiritual and social physical potential"[1].

"National sports aims to maintain and improve health and fitness, achievement, human quality, instill moral values and noble character, sportsmanship, discipline, strengthen and foster national unity and integrity, strengthen national resilience, and uphold the dignity, and honor of the nation" [1].

Physical fitness is one of the goals in achieving coaching and developing good sports and creating quality human resources, without physical fitness, these goals will not be achieved [2].

Furthermore, the importance of physical fitness is also included in the school curriculum where the goals of sports physical education and health are as follows: 1).To develop sports achievements in educational institutions, 2).To direct students to carry out sports activities according to their talents and interests.3).Develop, implement and pay attention to the potential, abilities of talents and interests of students as a whole, both through intracurricular and extracurricular activities.

Seeing the importance of education and physical fitness, the efforts that need to be carried out are by conducting sports coaching, as well as carrying out regular and regular sports activities. The development and development of sports is part of an effort to improve the quality of Indonesian people as a whole which is directed at improving physical, mental, and spiritual health of the people.To improve good physical fitness, an institution is needed, one of which is through Madrasah Tsanawiyah (MTs). Activities carried out at school must be directed and planned to achieve the desired goals. One of the important areas of study in schools to improve physical fitness is sports and health physical education. Meanwhile, it is expected that students who have good physical fitness will have a good influence on learning outcomes, because they have "physical fitness, have a healthy body, and also have a basis for dynamic and creative intellectual activity" (Cooper).

In general, students MTsN Lubuk Buaya Padang get to the school using public transport and by parents, and from the economic perspective, the parents are belonged to the middle economy. Generally, their parents work as employees or Civil Servants (PNS). Most of the students use public transportation either to go to school or to go home, so that they do less physical activity such as walking. This trends significantly influence the their physical fitness.

Madrasah Tsanawiyah Negeri (MTsN) Lubuk Buaya is one of the educational institutions which carries Physical Education and Health (Penjasorkes) subjects. This subject is conducted in 2 hours outside of school hours. With the existence of this subject, it is expected to increase the component of physical fitness. "Agility, balance, coordination, speed, power, reaction time, aerobic endurance, measurement of body composition, flexibility, strength and muscle endurance"[3].

Based on the opinion above, it is clear that physical fitness is a very important condition for every student in 
living their daily lives, especially in following lessons and other activities.One way to improve physical fitness is through regular and regular sports activities through school.Physical fitness has an important role in the daily activities of students, because good physical fitness is needed by students both in following the learning process at school and in achievement outside of school.In general, physical freshness can be interpreted as a person's ability to do daily work efficiently without causing excessive fatigue so that he still enjoys free time. How important is physical fitness for students, because if the student's physical freshness is good, it can help students in the learning process without feeling tired, lethargic and bored in the learning process. Furthermore, the authors do not know the extent of physical fitness of students of this school. Hence, and the authors are interested in examining more about "A Review of Physical Fitness Level of Students in MTsN Lubuk Buaya Koto Tangah District, Padang", and illustrate empirically according to the data obtained later.

\section{METHODOLOGY}

This type of research is descriptive research that aims to describe the symptoms or a situation at the time of the study. Descriptive research is one type of research that aims to describe systematically, factually and accurately identify certain facts and characteristics of the population, or try to describe phenomena in detail. The place for conducting research and data collection was at MTsN LubukBuaya,Koto Tangah District, Padang. The study was conducted on November.

The population in this study was 321 female students. The sample was 47 students who was taken purposively. The type of data used in this study are primary and secondary data. Primary data was data taken directly by the researcher, and secondary data was taken from documentation. The data was analyzed through statistical and descriptive analysis

\section{RESULTS AND DISCUSSION}

From the results of physical fitness tests conducted on 47 female students, it was found that the highest value was 18 and the lowest value was 10 , while the range was 8 . Based on the data, the mean was 14.49 , median was 15 , mode was 15 and Standard of deviation was 1.57. Furthermore, the distribution of physical fitness categories of female students table below:

Table 1. Frequency Distribution Females Student Physical Fitness.

\begin{tabular}{|c|c|c|c|}
\hline Score & Category & fa & $\mathrm{fr}$ \\
\hline $22-25$ & Very Good (BS) & 0 & $0 \%$ \\
\hline $18-21$ & Good (b) & 1 & $2.13 \%$ \\
\hline $14-17$ & Fair (S) & 33 & $70.21 \%$ \\
\hline $10-13$ & Poor $(\mathrm{K})$ & 13 & $27.66 \%$ \\
\hline $5-9$ & Very Poor $(\mathrm{KS})$ & 0 & $0 \%$ \\
\hline \multicolumn{2}{|r|}{ Total } & 47 & $100 \%$ \\
\hline
\end{tabular}

\author{
Information: \\ $\mathrm{fa}=$ absolute frequency \\ $\mathrm{fr}=$ relative frequency
}

Based on the table above, of the 47 female students who were taken as samples in this study, there was no students who had physical fitness in the category of "very good", for physical fitness the category "good" there was only 1 person $(2.13 \%)$ students. Furthermore, of the 47 students, 33 people $(70.21 \%)$ had "fair" physical fitness, while as many as 13 people $(27.66 \%)$ had physical fitness in the "poor" category. And none of the students had physical fitness in the "very poor" category.

Based on the results of research, on the assessment of physical fitness level of students of, the largest results obtained was $70.21 \%$ on "fair" category. This means that the level of physical fitness of students in the State Madrasah Tsanawiyah (MTsN) of LubukBuaya, Koto Tangah District, Padang is still moderate.This certainly will affect the health of these students.

In accordance with these findings, it can be said that students who were selected as samples in this study had moderate physical fitness.Physical fitness is the ability of organs in completing daily tasks without experiencing excessive fatigue. Physical freshness is the ability of a person to carry out daily tasks with full sincerity and responsibility, without feeling tired in a passionate way to enjoy the use of leisure time and face the possibility of various unexpected dangers. So that people who have good physical fitness can carry out other unexpected things under any circumstances, even though he has carried out many previous activities.

Physical freshness is essentially concerned with the person's ability and physical ability to carry out their daily tasks efficiently and effectively in a relatively long time without causing fatigue which means and still has the reserve power to carry out other activities. Without good physical fitness, we will quickly feel tired and tired in doing our daily work.This means that physical fitness is very important for everyone.

Physical fitness is a very important thing that every human being has and this physical fitness is related to the physical condition of a person to do a job.If the physical condition of a student is good, students will be able to study well as expected. Likewise, those students also need good physical fitness so that they can do all the learning activities in the school. In addition, with good physical fitness, they will remain enthusiastic and still be able to do other work after they return home from school.If students experience fatigue, it will reduce the enthusiasm of students in following the learning process well given by the school.

For a student, physical fitness is also needed to carry out activities, especially activities to gain dexterity, ability and high learning abilities. To get dexterity and high learning abilities certainly need to maintain physical fitness as well as possible. The most important thing to improve physical fitness is physical activity and regular exercise, the body needs oxygen to produce energy because the body does not store oxygen. Oxygen must be 
taken, the pulse is channeled to all organs of the body and tissues that require energy. The body's ability to do so depends on the level of physical fitness possessed.For people who have good physical fitness, it will be easy to take the oxygen needed by the body. Whereas people with low physical fitness levels, this is a significant difficulty.

In addition, to obtain a good level of physical fitness is also influenced by food factors, because food ingredients are needed for energy sources, the construction of body cells, biocatalyst components, and catabolism.Food must be in accordance with what is needed by the body both quantitatively and qualitatively.

Additionally, the environment is also a preventive element in order to realize a just and prosperous society, prosperous, and further to achieve full human[4]. Physical fitness is also influenced by environmentalhealth, so it is necessary to pay attention to problems around us such as waste, sewage, housing, food insects, and environmental pollution.

There are several ways to improve the physical fitness that can be done with some practice, namely: jogging, endurance, and flexibility[5].

So it can be concluded that the level of physical fitness of students in MTs Negeri (MTsN) Lubuk Buaya must be improved by doing physical activities and exercise regularly, eating nutritious foods, maintaining an environment where they live, as well as doing some exercise.

\section{CONCLUSIONS}

The results of the study stated that the physical fitness of students of the MTsN LubukBuaya Padang was categorized as "fair" with a percentage of $70.21 \%$. Thus, it is suggested that the school, the teacher, and parents should pay more attention to and maintain the students' physical fitness. The teachers can also develop modifications in physical education learning, because this can improve student learning motivation and their learning outcomes improve.In addition, parents need to meet the nutritional needs of their children, because malnutrition can disrupt health and have a negative impact on physical education learning outcomes, as well as in giving attention and supervision to their children in learning. Last, the relevant Health Office provides information to parents about understanding and nutritional needs and their effects on children's development and growth.

\section{REFERENCES}

[1] RI Ministry of National Education Law No 03 years About the National Education System. Ministry of National Education. 2005, hal 23.

[2] Ministry of National Education. Indonesian Physical Fitness Test for Children aged 10-12 years, Jakarta: Center for Physical Quality Development of the Ministry of National Education. 2010, pp 14-32.

[3] Ismaryati. "Sports Tests and Measurements". Surakarta: Surakarta UNS. 2006, pp 57-65.
[4] Gusril. "Motor Development in the Age of Children”. Padang: UNP Press. 2011, pp 78-90.

[5] Pekik, Djoko Irianto. "Panduan Praktis Berolahraga untuk Kebugaran Kesehatan". Yogyakarta: C.V Andi Offset. 2004, pp 45-50. 